\title{
Effect of moderate inlet temperatures in ultra-high-pressure homogenization treatments on physicochemical and sensory characteristics of milk
}

\author{
G. G. Amador-Espejo, ${ }^{\star} †$ A. Suàrez-Berencia, ${ }^{\star}$ B. Juan, ${ }^{\star}$ M. E. Bárcenas, $†$ and A. J. Trujillo*1 \\ ${ }^{*}$ Centre Especial de Recerca Planta de Tecnologia dels Aliments (CERPTA), XaRTA, TECNIO, MALTA Consolider, \\ Departament de Ciència Animal i dels Aliments, Universitat Autònoma de Barcelona, 08193 Bellaterra, Barcelona, Spain \\ †Departamento de Ingeniería Química, Alimentos y Ambiental, Universidad de las Américas Puebla, Sta. Catarina Mártir, Cholula, Puebla, \\ C.P. 72810, México
}

\section{ABSTRACT}

The effect of ultra-high-pressure homogenization (UHPH) on raw whole milk (3.5\% fat) was evaluated to obtain processing conditions for the sterilization of milk. Ultra-high-pressure homogenization treatments of 200 and $300 \mathrm{MPa}$ at inlet temperatures $(\mathrm{Ti})$ of 55 , 65,75 , and $85^{\circ} \mathrm{C}$ were compared with a UHT treatment $\left(138^{\circ} \mathrm{C}\right.$ for $\left.4 \mathrm{~s}\right)$ in terms of microbial inactivation, particle size and microstructure, viscosity, color, buffering capacity, ethanol stability, propensity to proteolysis, and sensory evaluation. The UHPH-treated milks presented a high level of microbial reduction, under the detection limit, for treatments at $300 \mathrm{MPa}$ with $\mathrm{Ti}$ of $55,65,75$, and $85^{\circ} \mathrm{C}$, and at $200 \mathrm{MPa}$ with $\mathrm{Ti}=85^{\circ} \mathrm{C}$, and few survivors in milks treated at $200 \mathrm{MPa}$ with $\mathrm{Ti}$ of 55,65 , and $75^{\circ} \mathrm{C}$. Furthermore, UHPH treatments performed at $300 \mathrm{MPa}$ with $\mathrm{Ti}=75$ and $85^{\circ} \mathrm{C}$ produced sterile milk after sample incubation $\left(30\right.$ and $\left.45^{\circ} \mathrm{C}\right)$, obtaining similar or better characteristics than UHT milk in color, particle size, viscosity, buffer capacity, ethanol stability, propensity to protein hydrolysis, and lower scores in sensory evaluation for cooked flavor.

Key words: ultra-high-pressure homogenization, milk sterilization, UHT milk

\section{INTRODUCTION}

Since its development, heat treatment has been by far the most applied technology to enhance milk shelf life, as it destroys pathogen microorganisms and most of the spoilage bacteria (Walstra et al., 2006). The cooked off-flavor, a result of the whey protein denaturation process caused by the temperature increase, is the greatest disadvantage of these treatments, along with the loss of some physicochemical and nutritional quality (Fox and McSweeney, 1998; Datta and Deeth, 2003; Walstra et al., 2006). From studies on the vari-

Received July 9, 2013.

Accepted November 1, 2013.

${ }^{1}$ Corresponding author: Toni.Trujillo@uab.es ous heat treatments applied to milk, UHT treatment may increase shelf life to up to 6 or even $8 \mathrm{mo}$, with the main problems associated with the treatment being cooked off-flavor development, protein gelation, and nutritional compound destruction (Datta and Deeth, 2003; Cattaneo et al., 2008; Chavan et al., 2011).

For these reasons, the food industry is developing new processes to treat milk, with the intention of reducing the use of heat, using what are known as nonthermal technologies. Within the nonthermal technologies, several applications of ultra-high-pressure homogenization (UHPH; 100-400 MPa), which has previously been used in the pharmaceutical, chemical, and biochemical industries (Popper and Knorr, 1990; Floury et al., 2000), have already been studied by the food industry, with interesting results. The process is similar to the conventional homogenization used in the dairy industry, with improvements in both the valve material, which helps to reach pressures up to $400 \mathrm{MPa}$, and the geometry of the valve (Floury et al., 2004; Diels and Michiels, 2006; Huppertz, 2011). The most important processing parameters are the operating pressure, inlet temperature $\left(\mathbf{T}_{\mathrm{i}}\right)$, and number of passes (Datta et al., 2005; Diels and Michiels, 2006; Donsì et al., 2009; Dumay et al., 2013).

The UHPH process applied to milk has shown interesting results, such as the achievement of finer emulsions due to particle size reduction (Hayes et al., 2005; Zamora et al., 2007; Donsì et al., 2009), bacterial load reduction (including the reduction of pathogenic microorganisms; Diels and Michiels, 2006; Briñez et al., 2007; Pereda et al., 2007; Donsì et al., 2009), enzyme inactivation (Hayes and Kelly, 2003b; Datta et al., 2005; Hayes et al., 2005; Pereda et al., 2007), structural changes in the milk proteins through partial disassociation, and changes in the coagulation properties of milk (Datta et al., 2005; Sandra and Dalgleish, 2007; Zamora et al., 2007; Grácia-Juliá et al., 2008; Roach and Harte, 2008).

The main mechanisms involved in microbial reduction by UHPH treatment are shear stress, high-speed collisions, impingement, and cavitation (Paquin, 1999; Diels and Michiels, 2006; Donsì et al., 2009; Dumay et 
al., 2013). Even though the UHPH technology can be considered a nonthermal technology, fluid temperature elevation does occur, but for a very small fraction of time, if an appropriate cooling system is applied after the valve. This elevation is due to a variety of phenomena, such as shear stress, turbulence, cavitation, and the transformation of kinetic energy into heat during the pressure increase (Datta et al., 2005; Diels and Michiels, 2006; Donsì et al., 2009). This temperature increase makes an important contribution to microbial reduction and other changes in milk characteristics.

Several authors have suggested the use of UHPH treatment to reach similar levels of microbial load reduction as heat pasteurization. In this regard, Hayes et al. (2005) applied UHPH treatments of $250 \mathrm{MPa}$ at $\mathrm{T}_{\mathrm{i}}$ $=45^{\circ} \mathrm{C}$ to milk, obtaining a microbial load decrease of 3 $\log \mathrm{cfu} / \mathrm{mL}$. Furthermore, Pereda et al. (2006), applied UHPH treatments of $300 \mathrm{MPa}$ at $\mathrm{T}_{\mathrm{i}}=30$ and $40^{\circ} \mathrm{C}$ and achieved microbial reductions of around $4 \log \mathrm{cfu} / \mathrm{mL}$. Smiddy et al. (2007) carried out UHPH treatments of 200 and $250 \mathrm{MPa}$ at $\mathrm{T}_{\mathrm{i}}$ of 55 and $70^{\circ} \mathrm{C}$, reaching microbial reductions of above $5 \log \mathrm{cfu} / \mathrm{mL}$. More recently, Ruiz-Espinosa et al. (2013) used UHPH treatments of $250 \mathrm{MPa}$ at $\mathrm{T}_{\mathrm{i}}=25^{\circ} \mathrm{C}$ with 3 passes, obtaining microbial reductions above $5 \log \mathrm{cfu} / \mathrm{mL}$. Other authors have shown that UHPH is able to produce milk with a shelf life similar to heat-pasteurized milk. Similarly, Pereda et al. (2007) attained a shelf life longer than 15 $\mathrm{d}$ in UHPH milk treated at $300 \mathrm{MPa}$ with a $\mathrm{T}_{\mathrm{i}}$ of 30 and $40^{\circ} \mathrm{C}$.

From these studies, it is important to notice the effect of inlet temperatures on microbial load reduction when it is combined with pressure treatments above $250 \mathrm{MPa}$. Nevertheless, at the moment, only a few studies have been published regarding the use of UHPH treatments with moderate inlet temperatures (between 50 and $90^{\circ} \mathrm{C}$ ) to obtain milk of a high microbiological quality (i.e., sterile milk) while maintaining the sensory characteristics and reducing physicochemical changes. For these reasons, the aim of this study was to explore the possibility of obtaining sterile milk by applying UHPH treatments at moderate inlet temperatures; to evaluate microbial reduction, sensory, and physicochemical changes; and to compare the results to those obtained from UHT milk.

\section{MATERIALS AND METHODS}

\section{Milk Supply}

Fresh raw bovine milk $(11.72 \pm 0.45 \%$ TS and 3.37 $\pm 0.09 \%$ protein) was obtained from a local producer (Can Badó, La Roca del Vallès, Spain), standardized at $3.5 \pm 0.06 \%$ fat, and then stored for $24 \mathrm{~h}$ at $4^{\circ} \mathrm{C}$.

\section{UHPH and UHT Milk Treatments}

The UHPH treatment of milk tested in this study was performed in a Stansted high-pressure homogenizer (model FPG11300; Stansted Fluid Power Ltd., Harlow, UK). The equipment comprises a high-pressure ceramic valve able to support $350 \mathrm{MPa}$ and a second pneumatic valve, located after the first, able to support up to $50 \mathrm{MPa}$. The high-pressure system consists of 2 intensifiers driven by a hydraulic pump. The flow rate of the milk in the homogenizer was approximately 120 $\mathrm{L} / \mathrm{h}$. To minimize temperature retention after treatment and its effect on milk properties, 2 spiral-type heat-exchangers were located behind the second valve, as described by Guamis et al. (2010). The $\mathrm{T}_{\mathrm{i}}$ and the temperature both before the first homogenization valve (T1) and after the homogenization process (T2) were monitored throughout the experiment. In all experiments, the outlet temperature was approximately $15^{\circ} \mathrm{C}$. Milk was UHPH treated under the following conditions: 200 and $300 \mathrm{MPa}$ at the first valve with $\mathrm{T}_{\mathrm{i}}$ of $55,65,75$, and $85^{\circ} \mathrm{C}$ without using the second valve.

Before UHT treatment, a traditional milk homogenization process was carried out in a double-stage Niro Soavi homogenizer (model X68P; GEA Niro Soavi, Parma, Italy) at $18+4 \mathrm{MPa}$ (first valve pressure + second valve pressure) at $65^{\circ} \mathrm{C}$. A UHT milk treatment was then applied in a tubular indirect Finamat heat exchanger (model 6500/010; GEA Finnah GmbH, Ahaus, Germany) at $138^{\circ} \mathrm{C}$ for $4 \mathrm{~s}$. Samples of both treatments were manually collected in sterile bottles $(50 \mathrm{~mL})$, in a laminar flow clean air bench cabinet (Mini V/PCR; Telstar, Terrassa, Spain), previously sterilized to obtain aseptic conditions.

Collected samples were immediately cold stored at $4^{\circ} \mathrm{C}$, except for those incubated for sterility control. Three replicates of each experiment were conducted.

\section{Compositional Analysis}

Protein and fat content were determined by duplicate using the Dumas and Gerber methods, respectively (IDF, 1981, 2002). The TS and ashes analyses were carried out according to the International Dairy Federation (IDF, 1987) and AOAC International (2000; method 945.46) standards, respectively. The milk $\mathrm{pH}$ was evaluated at $\mathrm{d} 1$ by electrode immersion with a micro pH-potenciometer (model 2001; Crison Instruments SA, Alella, Spain).

\section{Microbiological Analysis}

To determine the microbial load reduction obtained, before treatments the following microbial groups were 
enumerated in duplicate: total bacteria count was determined by the pour-plate method in plate count agar (Oxoid Ltd., Basingstoke, UK) and incubated for $48 \mathrm{~h}$ at $30^{\circ} \mathrm{C}$. To determine the total spore load, $5 \mathrm{~mL}$ of milk was heated for $5 \mathrm{~min}$ at $80^{\circ} \mathrm{C}$ and then enumerated by the pour-plate method in plate count agar (Oxoid Ltd.) and incubated for $48 \mathrm{~h}$ at $30^{\circ} \mathrm{C}$. Lactobacilli and lactococci were enumerated in de Man, Rogosa, and Sharpe (MRS) and M17 agar (Oxoid Ltd.) respectively, pour plated, and incubated for $72 \mathrm{~h}$ and $48 \mathrm{~h}$ respectively, at $30^{\circ} \mathrm{C}$. Coliform bacteria were enumerated on violet red bile glucose (VRBG) agar (Oxoid Ltd.) by pour plating, and incubated for $48 \mathrm{~h}$ at $37^{\circ} \mathrm{C}$. Coagulase-positive Staphylococcus spp. were enumerated on Baird-Parker agar (Oxoid Ltd.) with rabbit plasma fibrinogen (RPF) supplement and incubated for $24 \mathrm{~h}$ at $37^{\circ} \mathrm{C}$.

To evaluate the sterility of the milk, UHPH samples were incubated at 45 and $30^{\circ} \mathrm{C}$ for 7 and $15 \mathrm{~d}$, respectively, evaluating the total bacteria count and visually observing the samples. Microbial load reduction was calculated with the difference between the logarithms of colony counts of the untreated $\left(\mathrm{N}_{0}\right)$ and treated $(\mathrm{N})$ samples $\left(\log _{10} \mathrm{~N}_{0}-\log _{10} \mathrm{~N}\right)$.

\section{Particle Size Determination}

The particle size determination of milk samples were carried out using a Beckman Coulter laser diffraction particle size analyzer (LS 13320 series; Beckman Coulter Inc., Fullerton, CA). Samples were diluted in distilled water until an appropriate obscuration was obtained in the diffractometer cell. An optical model based on the Mie theory of light scattering by spherical particles was applied by using the following conditions: real refractive index: 1.471, refractive index of fluid (water): 1.332, imaginary refractive index: 0 , and pump speed: $20 \%$. The size distribution was characterized by the diameter below which 50 or $90 \%$ of the volume of particles were found $\left(\mathbf{D}_{50}\right.$ and $\mathbf{D}_{90}$, respectively), the Sauter diameter (surface-weighted mean diameter, $\mathbf{D}_{3,2}$ ), and the volume-weighted mean diameter value $\left(\mathbf{D}_{4,3}\right)$. Each sample was measured in triplicate.

\section{Viscosity Determination}

The milk sample viscosity was measured in duplicate at $20^{\circ} \mathrm{C}$ in a rotational rheometer (Haake RheoStress 1; Thermo Electron Corp., Karlsruhe, Germany), using an internal cylinder Z34 (DIN53019) and an external cylinder Z34 (DIN53018). Samples were subjected to a shear rate, increasing from 0 to $140 \mathrm{~s}^{-1}$ in $180 \mathrm{~s}$ and the experimental flow curves were fitted to the Oswald-de Waele rheological model.

\section{Color Determination}

The color values of the milk samples were determined using a Hunter laboratory colorimeter (mini Scan XETM; Hunter Associates Laboratory Inc., Reston, VA), based on the CIE $L^{*} a^{*} b^{*}$ color space [where $L^{*}=$ lightness $\left(L^{*}=0\right.$ yields black and $L^{*}=100$ indicates diffuse white), $a^{*}=$ position between red/magenta and green (negative values indicate green and positive values indicate magenta), and $b^{*}=$ position between yellow and blue (negative values indicate blue and positive values indicate yellow)], with an illuminant of D65 and a standard observer of $10^{\circ}$ being the colorimeter calibrated against white and black tile standards. Five milliliters of each milk sample was warmed to $20^{\circ} \mathrm{C}$ before analysis.

\section{Buffering Capacity and Ethanol Stability}

The buffering capacity in the milk samples was evaluated adding $100 \mu \mathrm{L}$ of $0.5 \mathrm{M} \mathrm{HCl}$ every $30 \mathrm{~s}$ in a $100-\mathrm{mL}$ milk sample. The final buffering capacity was counted when a constant $\mathrm{pH}$ of 4.5 was reached (Huppertz et al., 2004a). The ethanol stability in milk samples was determined by the standard alcohol test, according to the Food and Agriculture Organization of the United Nations (FAO, 2000).

\section{Milk Protein Hydrolysis}

To evaluate the possible proteolysis by residual milk enzymes after processing, UHT and UHPH milk samples were subjected to incubation at $37^{\circ} \mathrm{C}$ with a preservation agent $(0.05 \%$ thimerosal) for $7 \mathrm{~d}$. The $\mathrm{pH}$ 4.6-soluble nitrogen fraction in milk was prepared by precipitation of milk with a buffer made of $1 \mathrm{M}$ sodium acetate and $10 \%$ acetic acid $(\mathrm{pH} 4.6)$, followed by centrifugation at $4,500 \times g$ for $15 \mathrm{~min}$ at $4^{\circ} \mathrm{C}$. The supernatant containing the $\mathrm{pH}$ 4.6-soluble nitrogen fraction was filtered through Whatman 40 paper and kept frozen until used. Proteolysis was calculated as the percentage increase in the $\mathrm{pH}$ 4.6-soluble nitrogen fraction in relation to the total nitrogen content of milk, and determined by the Dumas combustion method (IDF, 2002) in raw, UHT, and UHPH milk on d 0 and 7 , in duplicate.

\section{Transmission Electron Microscopy}

To examine the changes in milk microstructure, raw, UHT, and UHPH milk samples were observed using transmission electron microscopy, preparing the samples as described by Cruz et al. (2007). Milk samples 
were mixed with glutaraldehyde (3\% final concentration) and then mixed with $2 \%$ low-temperature gelling agarose (1:1 ratio). After gelling, the gel obtained was cut into $1-\mathrm{mm}^{3}$ cubes. After that, the cubes were washed with $0.1 \mathrm{M}$ sodium cacodylate buffer $(\mathrm{pH} 7.2)$ for $30 \mathrm{~min}$, which was repeated again after $1 \mathrm{~h}$. Afterward, the cubes were left for $1 \mathrm{~h}$ and replaced with a 1 -mL solution containing $50 \%$ osmium tetroxide $(2 \%$ solution) and a $50 \%$ cacodylate/ $\mathrm{HCl}$ buffer. The cubes were left for $2 \mathrm{~h}$ before being replaced with $1 \mathrm{~mL}$ of uranium acetate for $30 \mathrm{~min}$. After that, the sample cubes were washed with water before the dehydration process was applied. Sample dehydration consisted of washing with 50,70 , and $90 \%$ ethanol ( $\mathrm{vol} / \mathrm{vol}$ ) for 5 , 30 , and $180 \mathrm{~min}$ respectively. The $100 \%$ ethanol was changed after 30 and $60 \mathrm{~min}$; EPON resin was then added (to preserve the histological structure) and the sample was laminated in 0.03 to 0.05 slides, which were dyed with acetate uranium and lead citrate to enable observation. Examination was performed with a Philips 201 transmission electron microscope at an acceleration voltage of $60 \mathrm{kV}$ (NL-5600 MD; Philips, Eindhoven, the Netherlands).

\section{Sensory Evaluation}

The sensory evaluation of milk samples was carried out by a direct comparative test between UHPH and UHT milk, based on the IDF 99C Standard (IDF, 2009). A panel of 10 trained judges was asked to evaluate sensory attributes, such as color, mouth feel, and a variety of flavors, such as bitter, cooked, salty, rancid, and metallic. The evaluation was carried out using a scale of 0 to 4 (where $0=$ no differences compared with UHT milk, 1 = minimal differences, $2=$ noticeable differences, $3=$ considerable differences, and $4=$ extreme differences). The sensory evaluation was undertaken between 2 and $4 \mathrm{~d}$ after milk treatments.

\section{Statistical Analysis}

The results were analyzed by ANOVA, using the software Minitab 15 (Minitab Inc., State College, PA).
The data were presented as mean \pm standard deviation. The Tukey test was used to compare sample data. Evaluations were based on a significance level of $P<$ 0.05 .

\section{RESULTS AND DISCUSSION}

\section{Temperature Increase During UHPH Treatments}

It is well known that the temperature of fluid increases after its transit through the homogenization valve in the UHPH treatment. This increase is due to various phenomena, such as shear stress, turbulence, cavitation, and the transformation of kinetic energy into heat during the pressure increase (Datta et al., 2005; Diels and Michiels, 2006; Donsì et al., 2009). Table 1 presents the temperature increase during the UHPH treatments applied in the current study, with measurements of the temperature of the fluid before (T1) and after (T2) it had passed through the homogenization valve. A linear temperature increase was calculated plotting T2 at different pressure treatments (200 and $300 \mathrm{MPa}$ ), obtaining a linear increase of 21.12, 19.7, 18.3, and $17.82^{\circ} \mathrm{C} / 100 \mathrm{MPa}$ at $\mathrm{T}_{\mathrm{i}}$ of $55,65,75$, and $85^{\circ} \mathrm{C}$, respectively.

A temperature increase in milk due to UHPH treatment has been reported by several authors using UHPH equipment with the same valve design (Stansted Fluid Power Ltd.). Pereda et al. (2007) reported an increase rate of $19.5^{\circ} \mathrm{C} / 100 \mathrm{MPa}$ in UHPH treatments of 200 and $300 \mathrm{MPa}$ at $40^{\circ} \mathrm{C}$. Hayes et al. (2005) described an increase rate of $16.6^{\circ} \mathrm{C} / 100 \mathrm{MPa}$ in UHPH treatments from 150 to $250 \mathrm{MPa}$ at $45^{\circ} \mathrm{C}$. Furthermore, Hayes and Kelly (2003a) obtained an increase of $17.6^{\circ} \mathrm{C} / 100 \mathrm{MPa}$, applying 50 to $200 \mathrm{MPa}$ at 6 to $10^{\circ} \mathrm{C}$. Thiebaud et al. (2003) presented an $18.5^{\circ} \mathrm{C} / 100 \mathrm{MPa}$ increase, using 100 to $300 \mathrm{MPa}$ at 4,14 , and $24^{\circ} \mathrm{C}$.

As discussed above, the UHPH process generates an increase in fluid temperature. To reduce the effect of this temperature increase on the physicochemical and sensory characteristics of milk, heat exchangers were placed after the homogenization valve, which rapidly

Table 1. Temperature control $^{1}$ chart in ultra-high-pressure homogenization treatments ${ }^{2}$

\begin{tabular}{lccc}
\hline $\begin{array}{l}\text { Homogenization } \\
\text { pressure }(\mathrm{MPa})\end{array}$ & $\begin{array}{c}\text { Inlet temperature } \\
\left({ }^{\circ} \mathrm{C}\right)\end{array}$ & $\begin{array}{c}\text { Temperature before the } \\
\text { homogenization valve T1 }\left({ }^{\circ} \mathrm{C}\right)\end{array}$ & $\begin{array}{c}\text { Temperature after the } \\
\text { homogenization valve T2 }\left({ }^{\circ} \mathrm{C}\right)\end{array}$ \\
\hline 200 & 55 & $63.7 \pm 0.6$ & $108.3 \pm 0.6$ \\
& 65 & $74.0 \pm 1.0$ & $115.0 \pm 1.0$ \\
& 75 & $80.0 \pm 0.0$ & $117.0 \pm 0.0$ \\
300 & 85 & $69.0 \pm 0.5$ & $120 \pm 0.1$ \\
& 55 & $78.3 \pm 0.6$ & $129.3 \pm 0.6$ \\
& 75 & $79.0 \pm 2.7$ & $135.0 \pm 0.0$ \\
& 85 & $85.3 \pm 0.2$ & $133.3 \pm 3.1$ \\
\hline
\end{tabular}

${ }^{1} \mathrm{~T} 1=$ temperature before the first homogenization valve; $\mathrm{T} 2=$ temperature after the homogenization process.

${ }^{2}$ Values are means $\pm \mathrm{SD}$ ( $\mathrm{n}=3$ independent experiments). 
reduced the fluid temperature to 15 to $17^{\circ} \mathrm{C}$ after treatment. Moreover, it is important to notice that even though a significant increase in the fluid temperature occurred after the homogenization valve (i.e., $\mathrm{T}_{\mathrm{i}}=85^{\circ} \mathrm{C}$ at $300 \mathrm{MPa}$ with $\left.\mathrm{T} 2=139^{\circ} \mathrm{C}\right)$, the residence time was very short $(<0.5 \mathrm{~s})$.

\section{Microbial Inactivation}

The initial bacterial load of raw milk is shown in Table 2. In this study, a significant reduction in bacteria count was achieved in all treatments applied $(\sim 5$ $\log \mathrm{cfu} / \mathrm{mL}$ ), presenting some surviving microorganisms (about $5 \mathrm{cfu} / \mathrm{mL}$ ) in milks treated at $200 \mathrm{MPa}$ at 55 , 65 , and $75^{\circ} \mathrm{C}$. In contrast, in all treatments applied at $300 \mathrm{MPa}$ and $200 \mathrm{MPa}$ with $\mathrm{T}_{\mathrm{i}}=85^{\circ} \mathrm{C}$, microbial counts under the detection level were obtained. The differences between the bacteria count inactivation found in the present work and other published studies may be explained by either the use of higher $T_{i}$ or the use of different numbers of homogenization passes (Diels and Michiels 2006; Donsì et al., 2009; Maresca et al., 2011; Dumay et al., 2013). In this way, the results of the current study were higher than those observed by Picart et al. (2006), using similar pressure levels (100-300 MPa), but applying a $\mathrm{T}_{\mathrm{i}}$ of $24^{\circ} \mathrm{C}$. In the study of Picart et al. (2006), the bacteria count inactivation achieved was $0.7,1.7,2.3$, and $2.9 \log \mathrm{cfu} / \mathrm{mL}$ in UHPH treatments at 100, 200, 250, and $300 \mathrm{MPa}$, respectively. Furthermore, Thiebaud et al. (2003) obtained lower microbial reductions ( 1 to $1.15 \log \mathrm{cfu} / \mathrm{mL}$ ) by applying UHPH treatments at $200 \mathrm{MPa}$ and $\mathrm{T}_{\mathrm{i}}=24^{\circ} \mathrm{C}$. Kheadr et al. (2002) obtained a bacteria inactivation count of $2 \log \mathrm{cfu} /$ $\mathrm{mL}$ in whole bovine milk ( $3.4 \%$ fat) after treatments at $200 \mathrm{MPa}$ at $\mathrm{T}_{\mathrm{i}}=28^{\circ} \mathrm{C}$, using 5 passes through the homogenization valve. Moreover, Hayes et al. (2005) reached inactivation levels of 1.83 and $3 \log \mathrm{cfu} / \mathrm{mL}$, using 200 and $250 \mathrm{MPa}$ at $\mathrm{T}_{\mathrm{i}} 45^{\circ} \mathrm{C}$, respectively. More recently, Ruiz-Espinosa et al. (2013) applied a response surface method to describe a combination of pressure levels and number of passes at 1 inlet temperature to achieve a $5-\log \mathrm{cfu} / \mathrm{mL}$ reduction. The results showed that 2 optimized UHPH processes of five 202-MPa passes and four $232-\mathrm{MPa}$ passes at $25^{\circ} \mathrm{C}$ would obtain a reduction in bacteria counts and Staphylococcus aureus (a baroresistant pathogen) of $5 \log \mathrm{cfu} / \mathrm{mL}$.

It is relevant to highlight the effect of pressure and inlet temperature on the inactivation obtained. Smiddy et al. (2007) evaluated the effect of pressure/ temperature and temperature by itself on the level of inactivation achieved. First, UHPH treatments were applied to milk (200 and $250 \mathrm{MPa}$ at $\mathrm{T}_{\mathrm{i}}=55$ and $70^{\circ} \mathrm{C}$ ), with the effect of temperature then being examined by passing the milk at the inlet temperature $\left(\mathrm{T}_{\mathrm{i}}\right.$
Table 2. Initial microbial load $(\log \mathrm{cfu} / \mathrm{mL})$ in raw milk storage at $4^{\circ} \mathrm{C}^{1}$

\begin{tabular}{lc}
\hline Microbiological group & $\begin{array}{c}\text { Load } \\
(\log \mathrm{cfu} / \mathrm{mL})\end{array}$ \\
\hline Total bacteria count & $5.8 \pm 0.3$ \\
Spore count & $1.0 \pm 0.4$ \\
Lactococci & $5.6 \pm 0.3$ \\
Lactobacilli & $4.3 \pm 0.5$ \\
Coagulase-positive Staphylococcus spp. & $\mathrm{ND}^{2}$ \\
Coliforms & $4.1 \pm 0.4$ \\
\hline
\end{tabular}

${ }^{1}$ Values are means $\pm \mathrm{SD}(\mathrm{n}=3$ independent experiments). ${ }^{2} \mathrm{ND}=$ not detected.

$=55$ and $70^{\circ} \mathrm{C}$ ), but without applying pressure. The results showed the significance of combining both effects, as heat treatments by themselves had previously accomplished a maximum reduction of $2 \log \mathrm{cfu} / \mathrm{mL}$. However, when UHPH treatments were applied, the initial load decreased to under the detection level $(\sim 5.3$ $\log \mathrm{cfu} / \mathrm{mL}$ ). Similarly, Picart et al. (2006) inoculated Listeria innocua, Micrococcus luteus, and Pseudomonas fluorescens in whole milk and evaluated the effect of the UHPH process (100-300 $\mathrm{MPa}$ at $\left.24^{\circ} \mathrm{C}\right)$, comparing it to the inactivation obtained by heat treatments (from 53 to $87^{\circ} \mathrm{C}$ for $4 \mathrm{~s}$ ), based on the temperature of the fluid once it has left the homogenization valve (T2). After treatments, the inactivation curves for both heat-treated and UHPH treated samples were plotted and the curves intercepted at 70,65 , and $64^{\circ} \mathrm{C}$ for $L$. innocua, M. luteus, and P. fluorescens, respectively. Below these intercepting points, the inactivation levels obtained for the 3 respective microorganisms were higher for UHPH treatments than heat treatment. In this section of the curve, those authors suggested that the microbial inactivation in UHPH was essentially due to the mechanical effects [such as shear stress, cavitation and (or) highspeed impacts] generated in the UHPH valve rather than the inactivation mechanisms associated with heat. Above the intercepting point $\left(64-70^{\circ} \mathrm{C}\right)$, the microbial inactivation achieved was lower in the UHPH treatments than in the heat treatment applied in the milk. In this case, the authors assumed that these results were based on the residence time after the fluid had passed through the homogenization valve $(\sim 215 \mathrm{~ms})$, being much less than the residence time for heat treatment applied (4 s). Nevertheless, those authors considered that heating the milk for $215 \mathrm{~ms}$ probably had no effect by itself in the inactivation achieved; but, it may induce some modifications in the cell membrane. These modifications in the membrane could lead to a synergistic effect with the mechanical effects taking place in the UHPH process.

Moreover, the effect of the heat component of the UHPH treatments on the inactivation achieved is evi- 
dent when comparing the results from the current study with those from Pereda et al. (2007), as both studies were carried out using the same equipment. Pereda et al. (2007) evaluated the inactivation obtained through the effect of pressure/ $\mathrm{T}_{\mathrm{i}}$ during the UHPH process, with the objective of comparing the effectiveness of UHPH technology with that of the heat pasteurization process. Using UHPH conditions of 200 and $300 \mathrm{MPa}$, but with less intense $\mathrm{T}_{\mathrm{i}}\left(30\right.$ and $\left.40^{\circ} \mathrm{C}\right)$, no significant difference in the inactivation level was found among treatments (3.2 and $3.5 \log \mathrm{cfu} / \mathrm{mL}$, respectively). However, when the results were compared with those from the current study (about $5.8 \log \mathrm{cfu} / \mathrm{mL}$ ), the difference was found to be due to the higher Ti, especially so in the treatments applying more severe $\mathrm{T}_{\mathrm{i}}(65,75$, and $\left.85^{\circ} \mathrm{C}\right)$.

In the current study, no coagulase-positive Staphylococcus spp. were found in raw milk samples, whereas other studies (Smiddy et al., 2007) have shown the complete inactivation of Staph. aureus in similar treatments (200 and $300 \mathrm{MPa}, \mathrm{T}_{\mathrm{i}}=55$ and $70^{\circ} \mathrm{C}$ ). RuizEspinosa et al. (2013) obtained 2.7 and $6 \log \mathrm{cfu} / \mathrm{mL}$ of inactivation by using UHPH treatments of $250 \mathrm{MPa}$ at $25^{\circ} \mathrm{C}$ with 1 and 5 passes, respectively.

Coliforms are used as an index of food contamination. In milk, high counts of coliforms indicate a deficiency in good manufacturing practice during milking, collection, or manipulation. In the current study, the coliform counts in the raw milk were $4.1 \log \mathrm{cfu} / \mathrm{mL}$; however, after treatment, counts were under the detection limit. Similar results regarding the complete inactivation of coliform counts were presented by Pereda et al. (2007), Smiddy et al. (2007), and Hayes et al. (2005). Other bacterial groups, such as lactobacilli and lactococci, have different resistance to UHPH, with the latter being more resistant to the UHPH process (Pereda et al., 2007). Nevertheless, in the current study, both microbial groups were inactivated to below the detection limit in all treatments applied. In this regard, Smiddy et al. (2007) reported lactobacilli inactivation rates of $3.8 \log \mathrm{cfu} / \mathrm{mL}$ in milk treated by UHPH at 200 and $250 \mathrm{MPa}$ with $\mathrm{T}_{\mathrm{i}}$ of 55 and $70^{\circ} \mathrm{C}$.

To evaluate the sterility of the samples obtained by applying different UHPH treatments (300 MPa at 55, 65,75 , and $85^{\circ} \mathrm{C}$ and $200 \mathrm{MPa}$ at $85^{\circ} \mathrm{C}$ ), they were incubated at 30 and $45^{\circ} \mathrm{C}$ for 15 and $7 \mathrm{~d}$, respectively. The microbial presence was evaluated based on protein coagulation (visual observation) and microbial count in plate count agar. The results showed that milks treated at $300 \mathrm{MPa}$ at 75 and $85^{\circ} \mathrm{C}$ were sterile during the incubation. On the other hand, the samples treated under less intense conditions presented protein coagulation and high microbial counts.

\section{Particle Size Evaluation}

Figure 1 shows the effect of UHPH and UHT treatments on particle size distribution with respect to raw milk. A bimodal characteristic distribution was found in raw milk: a $0.2-\mu \mathrm{m}$ peak, corresponding to casein micelles, and a second peak of $3.7 \mu \mathrm{m}$, corresponding to milk fat globules. After the treatments were applied, significant changes in particle size distribution could be observed. One of them was the change in the particle distribution from bimodal to monomodal when treatments of $200 \mathrm{MPa}$ were applied, with a considerable increase in the peak of around $0.2 \mu \mathrm{m}$. Moreover, the traditional homogenization carried out in the UHT process showed a change in the typical bimodal distribution of raw milk, with a diminution in the second peak intensity and a displacement of the first peak. In the samples treated at $300 \mathrm{MPa}$, no change was observed in the bimodal distribution, but a reduction in the intensity in the first peak and the presence of the tail at the end of the second peak $(\sim 3.7 \mu \mathrm{m})$ could be observed, with the last phenomena caused by the formation of fat aggregates or larger particles. Similar results in the particle distribution of whole milk were presented by Pereda et al. (2007), who applied UHPH treatments at 200 and $300 \mathrm{MPa}$ at $\mathrm{T}_{\mathrm{i}}$ of 30 and $40^{\circ} \mathrm{C}$.

With regard to the $\mathrm{D}_{50}$ and $\mathrm{D}_{90}$ parameters, both were reduced by conventional homogenization in UHT treatment from 2.68 and $4.90 \mu \mathrm{m}$ in raw milk to 0.45 and $3.2 \mu \mathrm{m}$, respectively (Table 3 ). The UHPH treatments were capable of a significant reduction in both parameters, with the exception of the $300 \mathrm{MPa} / 85^{\circ} \mathrm{C}$ treatment, which produced an increase in the $\mathrm{D}_{90}$ parameter. Samples treated at $200 \mathrm{MPa}$ always showed lower values for both parameters than those treated at $300 \mathrm{MPa}$. Moreover, the $\mathrm{T}_{\mathrm{i}}$ was seen to affect the $\mathrm{D}_{50}$ and $\mathrm{D}_{90}$ parameters in samples treated at $300 \mathrm{MPa}$, with a progressive increase in both parameters when the temperature increased from 55 to $85^{\circ} \mathrm{C}$. This increase in the $\mathrm{D}_{50}$ and $\mathrm{D}_{90}$ parameters in milk samples treated at $300 \mathrm{MPa}$ was also reported by Pereda et al. (2007) using a lower range of $\mathrm{T}_{\mathrm{i}}\left(30\right.$ and $\left.40^{\circ} \mathrm{C}\right)$.

Moreover, among the UHPH treatments applied, significant differences $(P<0.05)$ were found with regard to the pressure used in the $\mathrm{D}_{3,2}$ and $\mathrm{D}_{4,3}$ parameters. At the same $T_{i}, D_{3,2}$ and $D_{4,3}$ values were always lower in samples treated at $200 \mathrm{MPa}$ than in those treated at $300 \mathrm{MPa}$. Related to the $\mathrm{T}_{\mathrm{i}}$ used and for each pressure applied, no significant differences $(P>0.05)$ were found in the $\mathrm{D}_{4,3}$ and $\mathrm{D}_{3,2}$ parameters, except for the treatments performed at $85^{\circ} \mathrm{C}$, in which a significant increase was observed. Pereda et al. (2007) obtained similar results in the particle size distribution param- 


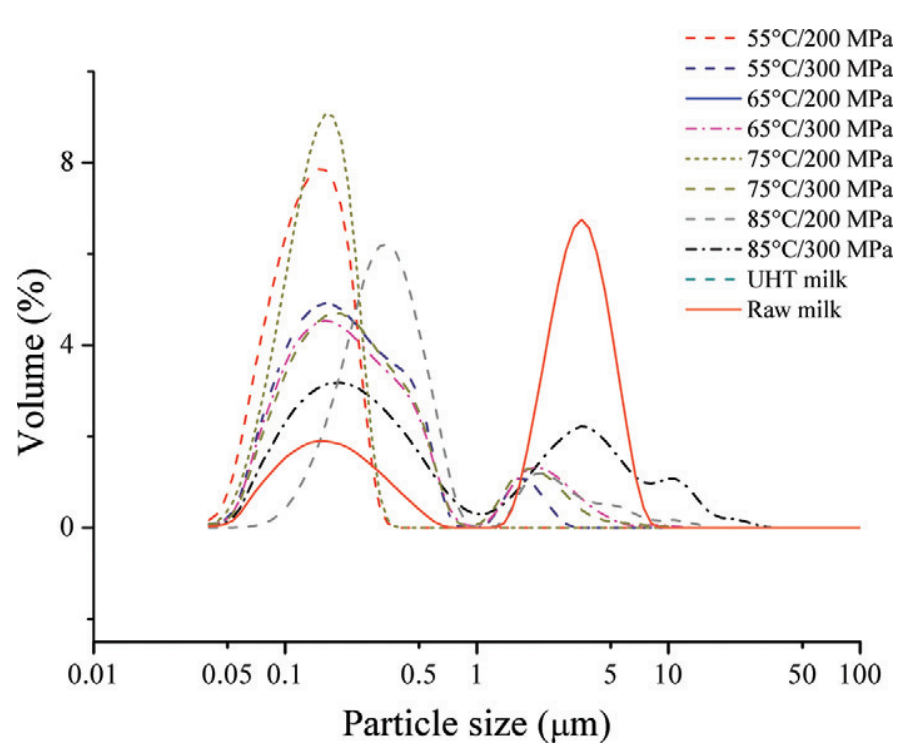

Figure 1. Particle size distribution in milk samples. Color version available in the online PDF.

eters in milk treated at 200 and $300 \mathrm{MPa}\left(\mathrm{T}_{\mathrm{i}}=30\right.$ and $40^{\circ} \mathrm{C}$ ), with significant differences in $\mathrm{D}_{3,2}$ between the homogenized-pasteurized milk $\left(18+2 \mathrm{MPa}\right.$ at $90^{\circ} \mathrm{C}$ for $15 \mathrm{~s})$ and UHPH treatments. Similarly, Thiebaud et al. (2003) presented an increase in both parameters in whole milk when the temperature was increased from 4 to $24^{\circ} \mathrm{C}$ at $300 \mathrm{MPa}$, reporting an increase from 0.20 to $1.27 \mu \mathrm{m}$ and 0.73 to $2.31 \mu \mathrm{m}$ for $\mathrm{D}_{3,2}$ and $\mathrm{D}_{4,3}$, respectively. In addition, Hayes et al. (2005) found similar values in parameter $\mathrm{D}_{4,3}$ in $\mathrm{UHPH}$ milk treated at 250 $\mathrm{MPa}$ and $45^{\circ} \mathrm{C}$ and commercial pasteurized whole milk (0.86 and $0.88 \mu \mathrm{m}$, respectively).

Variations in parameter $\mathrm{D}_{4,3}$ are due to the aggregation of small particles and their presence may be useful as a means of charting the phenomena of aggregation in food emulsions (Cortés-Muñoz, et al., 2009; Zamora et al., 2012). In UHPH milk samples treated at $300 \mathrm{MPa}$, these aggregation phenomena can be corroborated by the presence of a tail in the second peak (in the 1.9- to 2.1- $\mu \mathrm{m}$ range), a consequence of many simultaneous events in the homogenization valve, such as high speed collision between particles, cavitation, and turbulence, among others (Thiebaud et al., 2003; Diels and Michiels, 2006). This behavior has been described in several studies applying UHPH in the range of 250 to 300 $\mathrm{MPa}$, regardless of the food fluid material pressurized, such as soy milk (Cruz et al., 2007; Poliseli-Scopel et al., 2012) or bovine milk (Hayes et al., 2005; Pereda et al., 2007; Zamora et al., 2007). Furthermore, the sensibility of milk protein to aggregation depends on $\mathrm{UHPH}$ factors such as pressure and $\mathrm{T}_{\mathrm{i}}$ applied, and can lead to severe changes in functional properties by affecting the stability of the micelle components ( $\kappa$ CN, calcium phosphate, and hydrophobic interactions; Sandra and Dalgleish, 2007; Roach and Harte, 2008). Another explanation for the aggregation phenomena presented at $300 \mathrm{MPa}$ can be the mechanism by which fat coalesces and creams. Fat globules are stabilized by casein micelles, which are the last limiting component in this mechanism (Paquin, 1999; Hayes et al., 2005). The UHPH causes a rupture in the native fat globules, creating more fat globules in the process and, thus, increasing the amount of casein adsorbed into the fat globules to stabilize the system. In this regard, CanoRuiz and Richter (1997) reported a significant increase in the amount of casein adsorbed into fat globules when the pressure was elevated from 30 to $90 \mathrm{MPa}$. However, at pressures above $200 \mathrm{MPa}$, the amount of available casein may become limiting, leading to the partial ag-

Table 3. Particle size parameters $(\mu \mathrm{m})$ in raw and treated milks ${ }^{1}$

\begin{tabular}{lcccc}
\hline & \multicolumn{4}{c}{ Diameter $^{2}$} \\
\cline { 2 - 5 } Sample & $\mathrm{D}_{50}$ & $\mathrm{D}_{90}$ & $\mathrm{D}_{3,2}$ & $\mathrm{D}_{4,3}$ \\
\hline $\mathrm{Raw}$ & $2.68 \pm 0.31^{\mathrm{a}}$ & $4.90 \pm 0.38^{\mathrm{b}}$ & $0.43 \pm 0.08^{\mathrm{a}}$ & $3.00 \pm 0.91^{\mathrm{a}}$ \\
$\mathrm{UHT}^{3}$ & $0.45 \pm 0.02^{\mathrm{b}}$ & $3.20 \pm 0.60^{\mathrm{c}}$ & $0.39 \pm 0.03^{\mathrm{b}}$ & $1.35 \pm 0.38^{\mathrm{c}}$ \\
$55^{\circ} \mathrm{C}$ and $200 \mathrm{MPa}$ & $0.16 \pm 0.04^{\mathrm{e}}$ & $0.33 \pm 0.14^{\mathrm{f}}$ & $0.14 \pm 0.03^{\mathrm{d}}$ & $0.20 \pm 0.09^{\mathrm{f}}$ \\
$65^{\circ} \mathrm{C}$ and $200 \mathrm{MPa}$ & $0.14 \pm 0.01^{\mathrm{e}}$ & $0.23 \pm 0.00^{\mathrm{f}}$ & $0.13 \pm 0.01^{\mathrm{d}}$ & $0.15 \pm 0.01^{\mathrm{f}}$ \\
$75^{\circ} \mathrm{C}$ and $200 \mathrm{MPa}$ & $0.15 \pm 0.01^{\mathrm{e}}$ & $0.24 \pm 0.01^{\mathrm{f}}$ & $0.13 \pm 0.01^{\mathrm{d}}$ & $0.16 \pm 0.01^{\mathrm{f}}$ \\
$85^{\circ} \mathrm{C}$ and $200 \mathrm{MPa}$ & $0.32 \pm 0.07^{\mathrm{c}}$ & $2.78 \pm 0.58^{\mathrm{d}}$ & $0.23 \pm 0.08^{\mathrm{c}}$ & $0.88 \pm 0.01^{\mathrm{d}}$ \\
$55^{\circ} \mathrm{C}$ and $300 \mathrm{MPa}$ & $0.23 \pm 0.02^{\mathrm{d}}$ & $0.82 \pm 0.35^{\mathrm{e}}$ & $0.19 \pm 0.01^{\mathrm{c}}$ & $0.40 \pm 0.06^{\mathrm{e}}$ \\
$65^{\circ} \mathrm{C}$ and $300 \mathrm{MPa}$ & $0.25 \pm 0.03^{\mathrm{d}}$ & $1.46 \pm 0.63^{\mathrm{d}}$ & $0.21 \pm 0.03^{\mathrm{c}}$ & $0.51 \pm 0.10^{\mathrm{de}}$ \\
$75^{\circ} \mathrm{C}$ and $300 \mathrm{MPa}$ & $0.27 \pm 0.03^{\mathrm{d}}$ & $2.39 \pm 0.64^{\mathrm{d}}$ & $0.22 \pm 0.02^{\mathrm{c}}$ & $0.72 \pm 0.17^{\mathrm{d}}$ \\
$85^{\circ} \mathrm{C}$ and $300 \mathrm{MPa}$ & $0.40 \pm 0.02^{\mathrm{c}}$ & $7.16 \pm 0.29^{\mathrm{a}}$ & $0.23 \pm 0.01^{\mathrm{c}}$ & $2.33 \pm 0.27^{\mathrm{b}}$ \\
\hline
\end{tabular}

\footnotetext{
${ }^{\mathrm{a}-\mathrm{f}}$ Different superscript letters within a column indicate significant differences $(P<0.05)$.

${ }^{1}$ Values are means $\pm \mathrm{SD}$ ( $\mathrm{n}=3$ independent experiments).

${ }^{2} \mathrm{D}_{50}=$ diameter below which $50 \%$ of the volume of particles are found; $\mathrm{D}_{90}=$ diameter below which $90 \%$ of the volume of particles are found; $\mathrm{D}_{3,2}=$ Sauter diameter (surface-weighted mean diameter); $\mathrm{D}_{4,3}=$ volumeweighted mean diameter.

${ }^{3} \mathrm{UHT}=$ treatment at $138^{\circ} \mathrm{C}$ for $4 \mathrm{~s}$.
} 
glomeration of very small fat particles not stabilized by casein.

\section{Viscosity Determination}

Viscosity is an important property in milk that may change the flow conditions and is also related to the mouthfeel sensory attribute. Significant differences $(P$ $<0.05$ ) in viscosity values were found between $\mathrm{UHPH}$ samples treated at $300 \mathrm{MPa}$ at 65,75 , and $85^{\circ} \mathrm{C}$, with respect to raw, UHT, and UHPH milks treated at 200 and $300 \mathrm{MPa}$ at $55^{\circ} \mathrm{C}$ (Table 4). Moreover, an increase in viscosity was measured in UHPH-treated milks when the pressure was increased from 200 to $300 \mathrm{MPa}$. In this case, the sample that achieved the highest viscosity value was the sample treated at $300 \mathrm{MPa}$ with $\mathrm{T}_{\mathrm{i}}=$ $85^{\circ} \mathrm{C}$. The viscosity increase in UHPH milks treated at higher $\mathrm{T}_{\mathrm{i}}\left(75-85^{\circ} \mathrm{C}\right)$ and pressure $(300 \mathrm{MPa})$ can be related to the presence of large particles or aggregates due to the insufficient covering by the milk proteins (casein and whey proteins) of the new particles created. When protein is limited, there is no longer sufficient protein to fully stabilize the fat droplet interface and, therefore, larger particles or aggregates may be formed as a result of coalescence or bridging flocculation, increasing the milk viscosity. In this regard, Walstra et al. (2006) described that the presence of larger particles or aggregates increases the viscosity of the milk by increasing the volume of the dispersed phase. Furthermore, the increase in the viscosity when the UHPH samples were treated at the same pressure with an increment in the $\mathrm{T}_{\mathrm{i}}$ (from 55 to 65,75 , and $85^{\circ} \mathrm{C}$ ) could be related to the denaturation of whey proteins. This increase in temperature can lead, in cases when the temperature is extremely high, to the insolubility of serum proteins, increasing the viscosity of skim milk about $10 \%$, due to the increment in the voluminosity of the serum proteins (Walstra et al., 2006). However, these differences in the viscosity measurements in milk samples made by rheological analysis were not detected in the sensory evaluation. Similar results in the increase in viscosity when the pressure in the treated product was augmented were reported by Pereda et al. (2007) in a study applying similar pressure levels (200 and 300 $\mathrm{MPa}$ ) to milk but at $\mathrm{T}_{\mathrm{i}}=30$ to $40^{\circ} \mathrm{C}$; by Boeneke et al. (2009), who used 50,125, and $200 \mathrm{MPa}$; and also by Cortés-Muñoz et al. (2009) in oil-in-water emulsions UHPH treated at 100,200 , and $300 \mathrm{MPa}$ at $24^{\circ} \mathrm{C}$.

\section{Color Determination}

With regard to the color parameter $L^{*}$, the lowest value was for raw milk $(89.27 \pm 0.75)$, whereas the UHT and UHPH treatments showed a significant increase (Table 5). Although significant differences $(P<0.05)$ in the parameter $L^{*}$ between raw and homogenized milk samples were detected, no differences were detected between UHT and UHPH milks. Similar results were reported by Hayes and Kelly (2003a), Hayes et al. (2005), and Pereda et al. (2007), showing an increment in this parameter in treatments of 50,100, 150, and 200 $\mathrm{MPa}$ at $5^{\circ} \mathrm{C} ; 150,200$, and $250 \mathrm{MPa}$ at $45^{\circ} \mathrm{C}$; and 200 to $300 \mathrm{MPa}$ at $\mathrm{T}_{\mathrm{i}}$ of 30 and $40^{\circ} \mathrm{C}$. According to Walstra et al. (2006), this increase in the parameter $L^{*}$ is due to an increase in the number of fat globules, which can diffract light more effectively.

With regard to the other color parameters $\left(a^{*}\right.$ and $\left.b^{*}\right)$, no significant differences $(P>0.05)$ were found among raw, UHT, and UHPH milks. The color parameter $a^{*}$ showed a small increase with the UHPH process, which was higher in $200 \mathrm{MPa}$-treated milks. The color parameter $b^{*}$ showed a reduction when UHPH

Table 4. Viscosity, ethanol stability, and buffering capacity in raw and treated milks ${ }^{1}$

\begin{tabular}{lccc}
\hline Sample & $\begin{array}{c}\text { Viscosity } \\
(\mathrm{mPa} \times \mathrm{s})\end{array}$ & $\begin{array}{c}\text { Ethanol stability } \\
(\% \text { ethanol })\end{array}$ & $\begin{array}{c}\text { Buffering capacity } \\
(\mathrm{mL} \text { of } 0.5 \mathrm{M} \mathrm{HCl})\end{array}$ \\
\hline Raw & $1.47 \pm 0.2^{\mathrm{c}}$ & $80.47 \pm 2.17^{\mathrm{a}}$ & $\mathrm{ND}^{3}$ \\
$\mathrm{UHT}^{4}$ & $1.42 \pm 0.2^{\mathrm{c}}$ & $69.17 \pm 1.44^{\mathrm{gh}}$ & $21.55 \pm 0.21^{\mathrm{a}}$ \\
$55^{\circ} \mathrm{C} 200 \mathrm{MPa}$ & $1.27 \pm 0.00^{\mathrm{c}}$ & $73.33 \pm 1.44^{\mathrm{bc}}$ & $18.05 \pm 0.07^{\mathrm{cd}}$ \\
$65^{\circ} \mathrm{C} 200 \mathrm{MPa}$ & $1.26 \pm 0.1^{\mathrm{c}}$ & $74.17 \pm 1.44^{\mathrm{b}}$ & $17.60 \pm 0.28^{\mathrm{d}}$ \\
$75^{\circ} \mathrm{C} 200 \mathrm{MPa}$ & $1.29 \pm 0.1^{\mathrm{c}}$ & $70.83 \pm 1.44^{\mathrm{ef}}$ & $18.75 \pm 0.07^{\mathrm{b}}$ \\
$85^{\circ} \mathrm{C} 200 \mathrm{MPa}$ & $1.83 \pm 0.1^{\mathrm{b}}$ & $70.00 \pm 0.00^{\mathrm{fg}}$ & $18.70 \pm 0.14^{\mathrm{bc}}$ \\
$55^{\circ} \mathrm{C} 300 \mathrm{MPa}$ & $1.80 \pm 0.1^{\mathrm{b}}$ & $72.50 \pm 0.00^{\mathrm{cd}}$ & $18.55 \pm 0.07^{\mathrm{bc}}$ \\
$65^{\circ} \mathrm{C} 300 \mathrm{MPa}$ & $2.17 \pm 0.4^{\mathrm{a}}$ & $71.67 \pm 1.44^{\mathrm{de}}$ & $19.10 \pm 0.14^{\mathrm{b}}$ \\
$75^{\circ} \mathrm{C} 300 \mathrm{MPa}$ & $2.10 \pm 0.2^{\mathrm{ab}}$ & $70.00 \pm 0.00^{\mathrm{fg}}$ & $21.10 \pm 0.14^{\mathrm{a}}$ \\
$85^{\circ} \mathrm{C} 300 \mathrm{MPa}$ & $2.39 \pm 0.02^{\mathrm{a}}$ & $68.75 \pm 1.76^{\mathrm{h}}$ & $21.25 \pm 0.21^{\mathrm{a}}$ \\
\hline
\end{tabular}

${ }^{\mathrm{a}-\mathrm{h}}$ Different superscript letters within a same column indicate significant differences $(P<0.05)$. 
Table 5. Color parameters for raw and treated milks ${ }^{1}$

\begin{tabular}{lccc}
\hline & \multicolumn{3}{c}{ Color $^{2}$} \\
\cline { 2 - 4 } Sample & $L^{*}$ & $a^{*}$ & $b^{*}$ \\
\hline Raw & $89.27 \pm 0.75^{\mathrm{c}}$ & $-2.10 \pm 0.38^{\mathrm{a}}$ & $6.56 \pm 1.02^{\mathrm{a}}$ \\
$\mathrm{UHT}^{3}$ & $92.54 \pm 0.22^{\mathrm{b}}$ & $-2.10 \pm 0.89^{\mathrm{a}}$ & $6.79 \pm 1.15^{\mathrm{a}}$ \\
$55^{\circ} \mathrm{C}$ and $200 \mathrm{MPa}$ & $92.13 \pm 0.69^{\mathrm{b}}$ & $-2.67 \pm 0.26^{\mathrm{a}}$ & $4.95 \pm 1.26^{\mathrm{a}}$ \\
$65^{\circ} \mathrm{C}$ and $200 \mathrm{MPa}$ & $92.40 \pm 0.26^{\mathrm{b}}$ & $-2.64 \pm 0.14^{\mathrm{a}}$ & $5.38 \pm 0.58^{\mathrm{a}}$ \\
$75^{\circ} \mathrm{C}$ and $200 \mathrm{MPa}$ & $92.46 \pm 0.28^{\mathrm{b}}$ & $-2.57 \pm 0.09^{\mathrm{a}}$ & $5.39 \pm 0.55^{\mathrm{a}}$ \\
$85^{\circ} \mathrm{C}$ and $200 \mathrm{MPa}$ & $93.83 \pm 0.35^{\mathrm{a}}$ & $-2.62 \pm 0.02^{\mathrm{a}}$ & $5.40 \pm 0.01^{\mathrm{a}}$ \\
$55^{\circ} \mathrm{C}$ and $300 \mathrm{MPa}$ & $92.19 \pm 0.24^{\mathrm{b}}$ & $-2.36 \pm 0.11^{\mathrm{a}}$ & $5.50 \pm 0.30^{\mathrm{a}}$ \\
$65^{\circ} \mathrm{C}$ and $300 \mathrm{MPa}$ & $92.48 \pm 0.24^{\mathrm{b}}$ & $-2.33 \pm 0.08^{\mathrm{a}}$ & $6.03 \pm 0.25^{\mathrm{a}}$ \\
$75^{\circ} \mathrm{C}$ and $300 \mathrm{MPa}$ & $92.18 \pm 0.31^{\mathrm{b}}$ & $-2.36 \pm 0.05^{\mathrm{a}}$ & $5.74 \pm 0.67^{\mathrm{a}}$ \\
$85^{\circ} \mathrm{C}$ and $300 \mathrm{MPa}$ & $92.75 \pm 1.20^{\mathrm{ab}}$ & $-2.37 \pm 0.03^{\mathrm{a}}$ & $5.79 \pm 0.01^{\mathrm{a}}$ \\
\hline
\end{tabular}

${ }^{\mathrm{a}-\mathrm{c}}$ Different superscripts within a column indicate significant differences $(P<0.05)$.

${ }^{1}$ Data are means $\pm \mathrm{SD}$ ( $\mathrm{n}=3$ independent experiments).

${ }^{2} L^{*}=$ lightness $\left(L^{*}=0\right.$ yields black and $L^{*}=100$ indicates diffuse white), $a^{*}=$ position between red $/$ magenta and green (negative values indicate green and positive values indicate magenta), and $b^{*}=$ position between yellow and blue (negative values indicate blue and positive values indicate yellow).

${ }^{3} \mathrm{UHT}=$ treatment at $138^{\circ} \mathrm{C}$ for $4 \mathrm{~s}$.

technology was applied (fewer yellow tones); nevertheless, among the UHPH samples analyzed, no differences were found $(P>0.05)$. These results for both $a^{*}$ and $b^{*}$ parameters are contrary to those reported by other authors who have tested UHPH. Pereda et al. (2007) applied both UHPH treatments of 200 and $300 \mathrm{MPa}$ at 30 and $40^{\circ} \mathrm{C}$ and heat treatment $\left(90^{\circ} \mathrm{C}\right.$ for $\left.15 \mathrm{~s}\right)$, showing only small changes, with an increase in the $a^{*}$ parameter and a decrease in the $b^{*}$ parameter, depending on the UHPH treatment applied. Hayes and Kelly (2003a) and Hayes et al. (2005), with relatively less intense UHPH treatments $(50,100,150$, and $200 \mathrm{MPa}$ at 7 and $45^{\circ} \mathrm{C}$ ), presented small changes in both parameters. Nevertheless, even though significant differences existed in the instrumental evaluation of the samples, no visual differences were perceived among UHT and UHPH milks.

\section{Buffering Capacity Determination}

With regard to buffering capacity in milk samples, significant differences $(P<0.05)$ can be observed between some UHPH samples and UHT milk (Table 4). First, among UHT milk and UHPH treatments at 300 $\mathrm{MPa}$ at 65,75 , and $85^{\circ} \mathrm{C}$, no significant differences were detected $(P>0.05)$, requiring similar amounts of 0.5 $M \mathrm{HCl}$ to reduce their $\mathrm{pH}$ to 4.6. However, between UHT and UHPH treatments of $300 \mathrm{MPa}$ at $55^{\circ} \mathrm{C}$ and $200 \mathrm{MPa}$ at $55,65,75$, and $85^{\circ} \mathrm{C}$, significant differences were detected $(P<0.05)$, presenting lower amounts of acid (from 17.5 to $19 \mathrm{~mL}$ of $0.5 \mathrm{M} \mathrm{HCl}$ ) to achieve the same final $\mathrm{pH}$ value. Only small differences between the UHPH and UHT milks were found in the first acidification stages ( $\mathrm{pH} 6.5$ to 5.5), indicating similar buffering capacity of milks at this $\mathrm{pH}$ range. However, in the latter stages of acidification ( $\mathrm{pH} 5.5$ to 4.6$)$, UHPH milks treated at $300 \mathrm{MPa}$ with $\mathrm{T}_{\mathrm{i}}$ of 75 and $85^{\circ} \mathrm{C}$ and UHT milks required higher amounts of acid, indicating a higher buffering capacity for these milks compared with the other UHPH milks in this $\mathrm{pH}$ range (Figure 2).

The milk components that contribute to buffering capacity are soluble phosphate, colloidal calcium phosphate, citrate, bicarbonate, caseins, and whey proteins (McCarthy, 2002). Although slight differences exist between reports with regard to the contribution of milk components to buffering capacity, the most common distribution is $40,35,20$, and $5 \%$ for soluble minerals, caseins, colloidal calcium phosphate, and whey proteins, respectively (Salaün et al., 2005). According to Huppertz et al. (2004a), the buffering capacity of milk is determined by the calcium phosphate solubilization speed, with an inverse relationship between these parameters. This increase in the buffering capacity of milk that corresponds inversely with decreasing $\mathrm{pH}$ at values $<5.5$ is the result of the solubilization of colloidal calcium phosphate, which takes place during milk acidification. It is well known that heat treatment leads to a decrease in soluble calcium and inorganic phosphate, due to the precipitation of calcium phosphate, causing an increase in the mineral level in the colloidal phase, which may be reversed, depending on the intensity of the treatment (Gaucheron, 2005). Moreover, Zamora et al. (2007) observed that the amount of minerals in rennet whey from milk UHPH treated at $300 \mathrm{MPa}$ was lower than that produced by other treatments that applied lower pressures, suggesting a mineral transfer from the soluble to the colloidal phase caused by heat during UHPH treatment. The higher buffering capacity of milk samples treated at $300 \mathrm{MPa}$ with $\mathrm{T}_{\mathrm{i}}$ of 75 and 


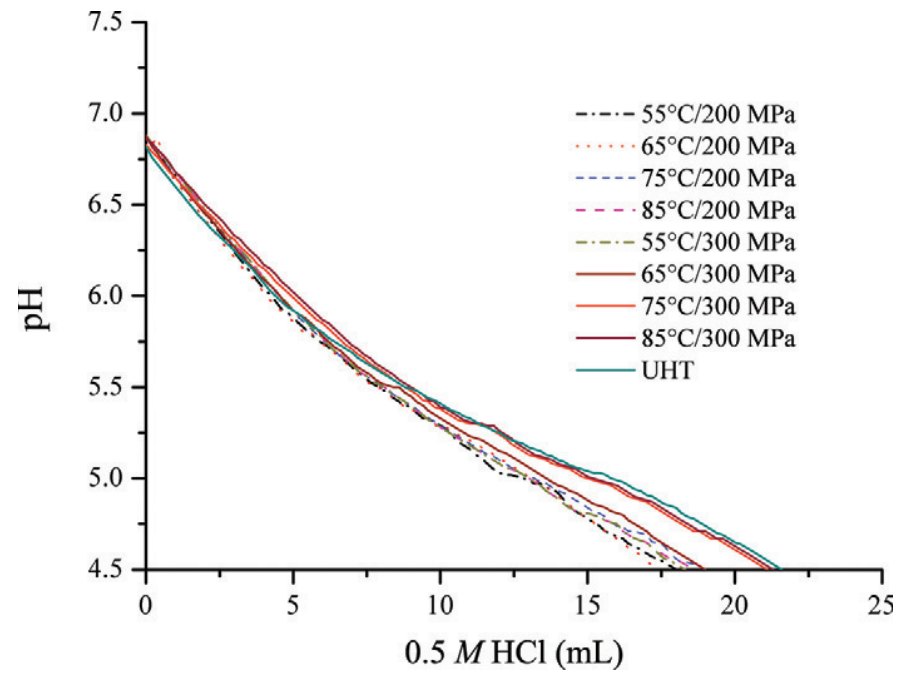

Figure 2. Buffering capacity in UHT milk and ultra-high-pressure homogenized (UHPH) milk. Color version available in the online PDF.

$85^{\circ} \mathrm{C}$ and $\mathrm{UHT}$ milks in the $\mathrm{pH}$ range 5.5 to 4.6 may be related to the solubilization of their colloidal calcium phosphate, which increases the levels of soluble calcium and phosphate even further compared with the other milk samples, thus providing greater buffering capacity.

\section{Ethanol Stability Determination}

Table 4 shows the ethanol stability of milks, which is the highest ethanol concentration that can be applied without causing protein coagulation. In general, the UHPH milks presented higher ethanol stability than UHT milk, except those treated at 75 and $85^{\circ} \mathrm{C}$ at $300 \mathrm{MPa}$, and at $85^{\circ} \mathrm{C}$ at $200 \mathrm{MPa}$, which presented similar values. In general, no great differences were found among samples treated at the same $\mathrm{T}_{\mathrm{i}}(55,65$, 75 , and $85^{\circ} \mathrm{C}$ ) and with the same pressures applied, but a decrease in ethanol stability could be observed when the pressure was increased from 200 to $300 \mathrm{MPa}$. Even though the mechanisms involved in the UHPH and high hydrostatic pressure are different, some points can be compared with regard to the pressure (only for a short period of time in $\mathrm{UHPH}$ ) and the elevated temperature, which is quickly reduced by a heat exchanger. Similar results were reported by Huppertz et al. (2004b), who used high hydrostatic pressure on milk $(250,400$, and $600 \mathrm{MPa}$ at $20^{\circ} \mathrm{C}$ for $30 \mathrm{~min}$ ) and evaluated the ethanol stability of the samples both immediately and $24 \mathrm{~h}$ after treatment. The results showed a reduction in the ethanol stability when high hydrostatic pressure was applied, decreasing from approximately $83 \%$ in untreated milk to approximately $64 \%$ in milk treated at 600 MPa. The decrease in ethanol stability was related to an increase in the soluble calcium present in high pres- surized milk and the possible disassociation of $\kappa-\mathrm{CN}$, due to micelle disintegration during treatment, causing a reduction in the steric stability of the casein micelles (Horne and Muir, 1990; Huppertz et al., 2004b). The effect of heat treatment on the ethanol stability of milk has been demonstrated by the molecular rearrangement of the soluble calcium to colloidal calcium, which then affects the steric stability of the micelle (Horne and Muir, 1990; Fox and McSweeney, 1998). In the case of the UHPH treatments, the mechanism that reduces the ethanol stability in milk could be explained by the combined effect of the mechanisms involved in the high hydrostatic pressure and heat treatments. Sandra and Dalgleish (2005) evaluated the modifications in the micelle casein structures in milk after UHPH treatment in the range of 41 to $186 \mathrm{MPa}$, and found a significant decrease in the micelle size with an increase of nonsedimentable caseins in the milk serum, such as $\kappa-\mathrm{CN}$, which may cause a reduction in the steric stability of the casein micelles. Zamora et al. (2007) evaluated the amount of calcium in the serum in UHPH treatments of 200 and $300 \mathrm{MPa}$ at $30^{\circ} \mathrm{C}$ and measured a decrease in the level of calcium in the serum, suggesting a mineral transfer from the soluble to the colloidal phase of milk. The lower ethanol stability of UHPH-treated milks, in comparison with raw milk, may be related to the higher calcium values and the dissociation of $\kappa-\mathrm{CN}$ in micelles produced by the UHPH treatment.

\section{Milk Protein Hydrolysis}

Plasmin and its inactive precursor plasminogen are the main proteolytic enzymes in milk that can survive severe heat treatments (Enright and Kelly, 1999). Their activity and proteolysis, in general, generate sensory problems in commercial sterile milks, because of the partial hydrolysis of $\beta$ - and $\alpha_{\mathrm{s}^{2}}-\mathrm{CN}$ (and more slowly in $\alpha_{\mathrm{s} 1}-\mathrm{CN}$ ), which leads to bitter and astringent flavor changes (Fajardo-Lira and Nielsen, 1998; Enright and Kelly, 1999; Santos et al., 2003). Psychrotrophic bacteria are another highly heat resistant proteolytic enzyme source in milk. These enzymes can survive UHT treatments and often cause a loss of quality during storage (Muir and Banks, 2000).

Among the treatments applied in this study, no significant differences $(P>0.05)$ were found between the soluble nitrogen found in milk samples treated by UHPH and UHT and then incubated for $7 \mathrm{~d}$ at $37^{\circ} \mathrm{C}$ with a preservation agent (data not shown). From this result, one can conclude that native or microbial milk proteases are inactivated by these treatments (UHPH or UHT) under the conditions that were used. Pereda et al. (2008) studied the proteolysis developed in milk treated by UHPH, applying similar pressure levels (200 


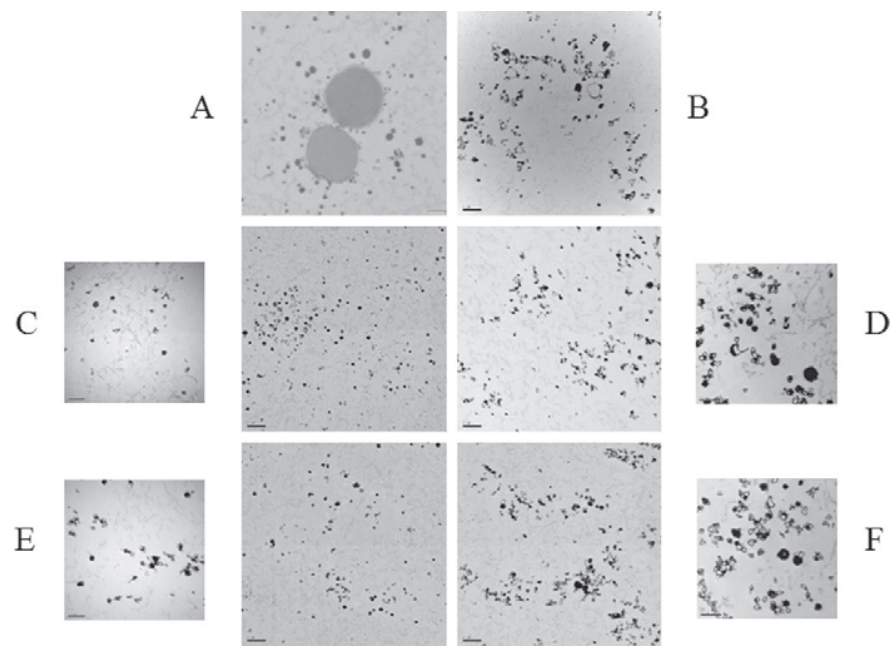

Figure 3. Transmission electron micrographs of raw (A) and UHT (B) at 10,000× magnification, and ultra-high-pressure homogenized (UHPH) milks treated at $200 \mathrm{MPa}$ at $55^{\circ} \mathrm{C}(\mathrm{C})$ and at $85^{\circ} \mathrm{C}(\mathrm{E})$, and $300 \mathrm{MPa}$ at $55^{\circ} \mathrm{C}(\mathrm{D})$ and at $85^{\circ} \mathrm{C}(\mathrm{F})$ at $10,000 \times$ and $30,000 \times$ magnification (bars represent 1 and $0.5 \mu \mathrm{m}$, respectively).

and $300 \mathrm{MPa})$ but with lower $\mathrm{T}_{\mathrm{i}}\left(30\right.$ and $\left.40^{\circ} \mathrm{C}\right)$ during cold storage at $4^{\circ} \mathrm{C}$, observing an increase in the inactivation of plasmin as the homogenization pressure increased. During storage, UHPH milk samples showed an increase in soluble nitrogen at $\mathrm{pH} 4.6$, in which the sample at $200 \mathrm{MPa}$ at $40^{\circ} \mathrm{C}$ obtained the highest increase, due to residual plasmin activity.

\section{Transmission Electron Microscopy}

The images obtained by transmission electron microscopy confirmed that the particle size results from the different treatments applied. Micrographs of raw milk (Figure 3A) show the typical native milk microstructure, with the characteristic sizes in both main components of milk (fat globule and casein micelle). In the UHT milk sample (Figure 3B), the fat globule size was significantly reduced and surrounded by submicelles or small micelle fractions with some aggregation phenomena, as can be observed in a conventional homogenization process. With regard to raw and UHT milk samples, UHPH-treated milk samples (Figure $3 \mathrm{C}-\mathrm{F}$ ) presented minor particle sizes (being more evident at $200 \mathrm{MPa}$ ) and different behavior, depending on the pressure and $\mathrm{T}_{\mathrm{i}}$ used. In relation to the pressure applied, the samples treated at $200 \mathrm{MPa}$ (Figure 3C and E) presented more homogenous particles $(\sim 0.2$ $\mu \mathrm{m})$ compared with the samples treated at $300 \mathrm{MPa}$ (Figure $3 \mathrm{D}$ and $\mathrm{F}$ ), in which an aggregation phenomena can be observed, as constituted by small fat globules, casein micelles, and possibly whey proteins undergoing a bimodal distribution. In relation to the $T_{i}$ applied, some differences still remain among UHPH treatments, where they form more aggregates with more intense treatments. This behavior was more evident between 55 and $85^{\circ} \mathrm{C}$ treatments, where considerable aggregates could be observed.

\section{Sensory Evaluation}

Results from sensory tests showed no significant differences $(P>0.05)$ in color, mouthfeel, or flavor defects such as bitterness, rancidity, or acid among the UHPH treatments applied compared with UHT milk as a reference (data not shown). Furthermore, UHPH milks presented less intense cooked flavor and slightly less salty flavor compared with UHT milk. In this regard, Boeneke et al. (2009) also reported no differences in flavor, appearance/color, and mouthfeel between whole milk treated by UHPH at $200 \mathrm{MPa}$ and heat treated, evaluated over a period of $3 \mathrm{wk}$.

\section{CONCLUSIONS}

The UHPH treatments at different $T_{i}$ proved to be efficient in achieving significant microbial inactivation close to the detection limit (200 $\mathrm{MPa}$ ) or under the detection limit (300 MPa). During UHPH milk incubation at 30 and $45^{\circ} \mathrm{C}$, treatments performed at $300 \mathrm{MPa}$ with $\mathrm{T}_{\mathrm{i}}$ of 75 or $85^{\circ} \mathrm{C}$ seem to be the most adequate processing conditions to obtain milk sterilization with UHPH technology. The UHPH reduced particle size and produced milk with better ethanol stability compared with UHT milk, while maintaining a similar buffering capacity. Furthermore, these treatments were able to produce milk with less intense cooked flavor than the UHT milk, with no difference in color, mouthfeel, rancidity, or acidity being found, either. Even though more studies of sterile UHPH milk after its aseptic packaging and during its storage are needed to understand changes related to the UHPH process and milk storage, the results have shown that UHPH treatments at 300 $\mathrm{MPa}$ with $\mathrm{T}_{\mathrm{i}}$ of 75 or $85^{\circ} \mathrm{C}$ are a real alternative to heat processing.

\section{ACKNOWLEDGMENTS}

The authors acknowledge the Ministerio de Ciencia e Innovación (Madrid, Spain; project AGL2009-07087) and the Ministerio de Educación y Ciencia (Madrid, Spain; project Consolider CSD2007-00045) for the financial support given to this investigation. The authors kindly thank M. Hernández-Herrero [Centre Especial de Recerca Planta de Tecnologia dels Aliments (CERPTA), XaRTA, TECNIO, MALTA Consolider, Departament de Ciència Animal i dels Aliments, Universitat 
Autònoma de Barcelona, Barcelona, Spain] for her assistance in microbiology. Author G. G. Amador-Espejo acknowledges the Consejo Nacional de Ciencia y Tecnología (CONACYT, Mexico City, Mexico; Scholarship 311522 ) for the doctoral fellowship.

\section{REFERENCES}

AOAC International. 2000. Ash determination in milk. Method 945.46 in Official Methods of Analysis. AOAC International, Washington, DC.

Boeneke, C. A., A. Pastorek, and K. J. Aryana. 2009. Effect of high pressure homogenization on milk. Milchwissenschaft 64:40-42.

Briñez, W. J., A. X. Roig-Sagués, M. M. Hernández Herrero, and B. G. López. 2007. Inactivation of Staphylococcus spp. strains in whole milk and orange juice using ultra high pressure homogenisation at inlet temperatures of 6 and $20^{\circ} \mathrm{C}$. Food Contr. 18:1282-1288.

Cano-Ruiz, M. E., and R. L. Richter. 1997. Effect of homogenization pressure on the milk fat globule membrane proteins. J. Dairy Sci. 80:2732-2739. http://dx.doi.org/10.3168/jds.S00220302(97)76235-0.

Cattaneo, S., F. Masotti, and L. Pellegrino. 2008. Effects of overprocessing on heat damage of UHT milk. Eur. Food Res. Technol. 226:1099-1106.

Chavan, R. S., S. R. Chavan, C. D. Khedkar, and A. H. Jana. 2011 UHT milk processing and effect of plasmin activity on shelf life: A review. Comp. Rev. Food Sci. Food Safety 10:251-268.

Cortés-Muñoz, M., D. Chevalier-Lucia, and E. Dumay. 2009. Characteristics of submicron emulsions prepared by ultra-high pressure homogenisation: Effect of chilled or frozen storage. Food Hydrocoll. 23:640-654. http://dx.doi.org/10.1016/j.foodhyd.2008.07.023

Cruz, N., M. Capellas, M. Hernández, J. Trujillo, B. Guamis, and V. Ferragut. 2007. Ultra high pressure homogenization of soymilk: Microbiological, physicochemical and microstructural characteristics. Food Res. Int. 40:725-732. http://dx.doi.org/10.1016/j. foodres.2007.01.003.

Datta, N., and H. C. Deeth. 2003. Diagnosing the cause of proteolysis in UHT milk. Lebensm. Wiss. Technol. 36:173-182.

Datta, N., M. G. Hayes, H. C. Deeth, and A. L. Kelly. 2005. Significance of frictional heating for effects of high pressure homogenisation on milk. J. Dairy Res. 72:393-399.

Diels, A. M. J., and C. W. Michiels. 2006. High-pressure homogenization as a non-thermal technique for the inactivation of microorganisms. Crit. Rev. Microbiol. 32:201-216. http://dx.doi. org / 10.1080/10408410601023516.

Donsì, F., G. Ferrari, E. Lenza, and P. Maresca. 2009. Main factors regulating microbial inactivation by high-pressure homogenization: Operating parameters and scale of operation. Chem. Eng. Sci. 64:520-532. http://dx.doi.org/10.1016/j.ces.2008.10.002

Dumay, E., D. Chevalier-Lucia, L. Picart-Palmade, A. Benzaria, A Gràcia-Julià, and C. Blayo. 2013. Technological aspects and potential applications of (ultra) high-pressure homogenisation. Trends Food Sci. Technol. 31:13-26.

Enright, E., and A. L. Kelly. 1999. The influence of heat treatment of milk on susceptibility of casein to proteolytic attack by plasmin. Milchwissenschaft 54:491-493.

Fajardo-Lira, C. E., and S. S. Nielsen. 1998. Effect of psychrotrophic microorganisms on the plasmin system in milk. J. Dairy Sci. 81:901-908.

FAO (Food and Agriculture Organization of the United Nations). 2000. Quality control manual: Raw milk and milk products. FAO, Rome, Italy.

Floury, J., A. Desrumaux, and J. Lardières. 2000. Effect of high-pressure homogenization on droplet size distributions and rheological properties of model oil-in-water emulsions. Innov. Food Sci. Emerg. Technol. 1:127-134.

Floury, J., J. Legrand, and A. Desrumaux. 2004. Analysis of a new type of high pressure homogeniser. Part B. Study of droplet breakup and recoalescence phenomena. Chem. Eng. Sci. 59:1285-1294.
Fox, P. F., and P. L. H. McSweeney. 1998. Dairy Chemistry and Biochemistry. Blackie Academic \& Professional, London, UK.

Gaucheron, F. 2005. The minerals of milk. Reprod. Nutr. Dev. $45: 473-483$.

Grácia-Juliá, A., M. René, M. Cortés-Muñoz, L. Picart, T. LópezPedemonte, D. Chevalier, and E. Dumay. 2008. Effect of dynamic high pressure on whey protein aggregation: A comparison with the effect of continuous short-time thermal treatments. Food Hydrocoll. 22:1014-1032.

Guamis, B., A. J. Trujillo, V. Ferragut, M. Buffa, and T. López-Pedemonte. 2010. Sistema continuo y procedimiento de esterilización y estabilización física de fluidos bombeables mediante ultra alta presión de homogeneización. Universitat Autònoma de Barcelona, assignee. European Patent No. 10380094.2.

Hayes, M. G., P. F. Fox, and A. L. Kelly. 2005. Potential applications of high pressure homogenisation in processing of liquid milk. J. Dairy Res. 72:25-33. http://dx.doi.org/10.1017/S0022029904000524.

Hayes, M. G., and A. L. Kelly. 2003a. High pressure homogenisation of raw whole bovine milk (a) effects on fat globule size and other properties. J. Dairy Res. 70:297-305. http://dx.doi.org/10.1017/ S0022029903006320.

Hayes, M. G., and A. L. Kelly. 2003b. High pressure homogenisation of milk (b) effects on indigenous enzymatic activity. J. Dairy Res. 70:307-313. http://dx.doi.org/10.1017/S0022029903006319.

Horne, D. S., and D. D. Muir. 1990. Alcohol and heat stability of milk protein. J. Dairy Sci. 73:3613-3626.

Huppertz, T. 2011. Homogenization of milk. High-pressure homogenizers. Pages 755-760 in Encyclopedia of Dairy Sciences. E.-C. J. W. Fuquay, ed. Academic Press, San Diego, CA.

Huppertz, T., P. F. Fox, and A. L. Kelly. 2004a. Influence of high pressure treatment on the acidification of bovine milk by lactic acid bacteria. Milchwissenschaft 59:246-249.

Huppertz, T., S. Grosman, P. F. Fox, and A. L. Kelly. 2004b. Heat and ethanol stabilities of high-pressure-treated bovine milk. Int. Dairy J. 14:125-133.

IDF (International Dairy Federation). 1981. Milk-Determination of fat content-Gerber butyrometers. Vol. 105. IDF, Brussels, Belgium.

IDF (International Dairy Federation). 1987. Milk, cream and evaporated milk-Determination of total solids content (reference method). Standard 21B. IDF, Brussels, Belgium.

IDF (International Dairy Federation). 2002. Milk and milk productsDetermination of nitrogen content-Routine method using combustion according to the Dumas principle. Standard 185. IDF, Brussels, Belgium.

IDF (International Dairy Federation). 2009. Milk and milk productsSensory analysis-Part 2: Recommended methods for sensory evaluation. ISO 22935-2. IDF 099-2:2009. IDF, Brussels, Belgium.

Kheadr, E. E., J. Vachon, P. Paquin, and I. Fliss. 2002. Effect of dynamic high pressure on microbiological, rheological and microstructural quality of Cheddar cheese. Int. Dairy J. 12:435-446. http://dx.doi.org/10.1016/S0958-6946(01)00104-2.

Maresca, P., F. Dons, and G. Ferrari. 2011. Application of a multi-pass high-pressure homogenization treatment for the pasteurization of fruit juices. J. Food Eng. 104:364-372.

McCarthy, O. J. 2002. Physical and physico-chemical properties of milk. Pages 467-477 in Encyclopedia of Dairy Sciences. E.-C. J. W. Fuquay, ed. Academic Press, San Diego, CA

Muir, D., and M. Banks. 2000. Milk and milk products. Pages 197-218 in The Stability and Shelf-Life of Food. D. Kilcast and P. Subramaniam, ed. Woodhead Publishing, Boca Raton, FL.

Paquin, P. 1999. Technological properties of high pressure homogenizers: The effect of fat globules, milk proteins, and polysaccharides. Int. Dairy J. 9:329-335

Pereda, J., V. Ferragut, M. Buffa, B. Guamis, and A. J. Trujillo. 2008. Proteolysis of ultra-high pressure homogenised treated milk during refrigerated storage. Food Chem. 111:696-702.

Pereda, J., V. Ferragut, B. Guamis, and A. J. Trujillo. 2006. Effect of ultra high-pressure homogenisation on natural-occurring microorganisms in bovine milk. Milchwissenschaft 61:245-248. 
Pereda, J., V. Ferragut, J. M. Quevedo, B. Guamis, and A. J. Trujillo. 2007. Effects of ultra-high pressure homogenization on microbial and physicochemical shelf life of milk. J. Dairy Sci. 90:1081-1093. http://dx.doi.org/10.3168/jds.S0022-0302(07)71595-3.

Picart, L., M. Thiebaud, M. René, J. Pierre Guiraud, J. C. Cheftel, and E. Dumay. 2006. Effects of high pressure homogenisation of raw bovine milk on alkaline phosphatase and microbial inactivation. A comparison with continuous short-time thermal treatments. J. Dairy Res. 73:454-463. http://dx.doi.org/10.1017/ S0022029906001853.

Poliseli-Scopel, F. H., M. Hernández-Herrero, B. Guamis, and V. Ferragut. 2012. Comparison of ultra high pressure homogenization and conventional thermal treatments on the microbiological, physical and chemical quality of soymilk. Lebenson. Wiss. Technol. $46: 42-48$.

Popper, L., and D. Knorr. 1990. Applications of high-pressure homogenization for food preservation. Food Technol. 44:84-89.

Roach, A., and F. Harte. 2008. Disruption and sedimentation of casein micelles and casein micelle isolates under high-pressure homogenization. Innov. Food Sci. Emerg. Technol. 9:1-8.

Ruiz-Espinosa, H., G. G. Amador-Espejo, M. E. Barcenas-Pozos, J. O. Angulo-Guerrero, H. S. Garcia, and J. Welti-Chanes. 2013. Multiple-pass high-pressure homogenization of milk for the development of pasteurization-like processing conditions. Lett. Appl. Microbiol. $56: 142-148$.

Salaün, F., B. Mietton, and F. Gaucheron. 2005. Buffering capacity of dairy products. Int. Dairy J. 15:95-109.

Sandra, S., and D. G. Dalgleish. 2005. Effects of ultra-high-pressure homogenization and heating on structural properties of casein mi- celles in reconstituted skim milk powder. Int. Dairy J. 15:10951104. http://dx.doi.org/10.1016/j.idairyj.2004.11.015.

Sandra, S., and D. G. Dalgleish. 2007. The effect of ultra high-pressure homogenization (UHPH) on rennet coagulation properties of unheated and heated fresh skimmed milk. Int. Dairy J. 17:10431052 .

Santos, M. V., Y. Ma, Z. Caplan, and D. M. Barbano. 2003. Sensory threshold of off-flavors caused by proteolysis and lipolysis in milk. J. Dairy Sci. 86:1601-1607.

Smiddy, M. A., J.-E. Martin, T. Huppertz, and A. L. Kelly. 2007. Microbial shelf-life of high-pressure-homogenised milk. Int. Dairy J. $17: 29-32$.

Thiebaud, M., E. Dumay, L. Picart, J. P. Guiraud, and J. C. Cheftel. 2003. High-pressure homogenisation of raw bovine milk. Effects on fat globule size distribution and microbial inactivation. Int. Dairy J. 13:427-439. http://dx.doi.org/10.1016/S0958-6946(03)00051-7.

Walstra, P., T. J. Geurts, and J. T. M. Wouters. 2006. Dairy Science and Technology. CRC Press, Boca Raton, FL.

Zamora, A., V. Ferragut, B. Guamis, and A. J. Trujillo. 2012. Changes in the surface protein of the fat globules during ultra-high pressure homogenisation and conventional treatments of milk. Food Hydrocoll. 29:135-143.

Zamora, A., V. Ferragut, P. D. Jaramillo, B. Guamis, and A. J. Trujillo. 2007. Effects of ultra-high pressure homogenization on the cheese-making properties of milk. J. Dairy Sci. 90:13-23. 